\title{
Differences in the Detailed Milk Mineral Composition of Italian Local and Saanen Goat Breeds
}

\author{
Sarah Currò ${ }^{1}\left(\mathbb{D}\right.$, Massimo De Marchi ${ }^{1}$, Salvatore Claps ${ }^{2}$, Angela Salzano ${ }^{3}$, Pasquale De Palo ${ }^{4} \mathbb{D}$, \\ Carmen L. Manuelian ${ }^{1, *(1)}$ and Gianluca Neglia ${ }^{3}$ \\ 1 Department of Agronomy, Food, Natural resources, Animals and Environment, University of Padova, Viale \\ dell'Università 16, 35020 Legnaro (PD), Italy \\ 2 Council for Agricultural Research and Analysis of Agricultural Economy Analysis, Research Centre for \\ Animal Production and Aquaculture, S.S.7 Via Appia, 85051 Bella Muro (PZ), Italy \\ 3 Department of Veterinary Medicine and Animal Production (DMVPA), University of Naples Federico II, \\ Naples, Via Federico Delpino 1, 80137 Napoli (NA), Italy \\ 4 Department of Veterinary Medicine, University of Bari Aldo Moro, S.P. per Casamassima km 3, \\ 70010 Valenzano (BA), Italy \\ * Correspondence: carmenloreto.manuelianfuste@unipd.it; Tel.: +39-049-827-2633
}

Received: 9 June 2019; Accepted: 28 June 2019; Published: 2 July 2019

Simple Summary: This study quantified major and trace minerals in milk of five Italian local goat breeds and a cosmopolitan goat breed throughout lactation. Significant differences were detected in milk minerals composition across week of lactation, with greater concentration at the end than at the beginning of the lactation for almost all minerals, while only $\mathrm{P}, \mathrm{Mg}$ and $\mathrm{Zn}$ milk content differed among breeds. Due to the growing interest of consumers in goat milk and derived products, the characterisation of milk mineral contents could contribute to valorise autochthonous breeds.

\begin{abstract}
Very little information about local breed goat milk is available, which is relevant for biodiversity preservation and local cheese production. This study aimed to evaluate the effect of breed and week of lactation on milk mineral profile of five Italian local breeds (Garganica, Girgentana, Jonica, Maltese and Mediterranean Red) and a cosmopolitan breed (Saanen). Sixty goats (10 per breed) from an experimental farm were enrolled in the study and sampled every 2 weeks for milk gross composition analysis. In addition, an individual milk sample was collected monthly from 42 goats (seven goats per breed) for mineral determination through inductively coupled plasma optical emission spectrometry. Data were analysed using a mixed linear model with repeated measures, including breed and week of lactation as fixed effects. Week of lactation affected mineral contents, except for B, being lower in early than late lactation, whereas, breed affected only $\mathrm{P}, \mathrm{Mg}$ and $\mathrm{Zn}$. Mediterranean Red and Jonica breeds' milk was richer in P than Maltese, and in $\mathrm{Zn}$ than Maltese, Girgentana and Saanen breeds. For Mg, only Saanen differed from Maltese. Such information might be useful for the valorisation of goat milk produced by autochthonous breeds.
\end{abstract}

Keywords: doe; indigenous breed; lactation; major mineral; trace element

\section{Introduction}

Europe produces approximately $15 \%\left(2.8 \times 10^{6}\right.$ tons $)$ of the world's goat milk $\left(18.6 \times 10^{6}\right.$ tons) [1] and $95 \%$ of this amount is transformed into dairy products [2]. Goat cheese production corresponds to $2.3 \%$ ( $52 \times 10^{4}$ tons) of worldwide cheese production $\left(23 \times 10^{6}\right.$ tons) [1], and several goat cheeses have protected designation status. In the last decade, the Italian goat milk and cheese production has increased $17 \%$ ( 24.9 to $29.2 \times 10^{3}$ tons) and $32 \%$ (3.4 to $4.5 \times 10^{3}$ tons), respectively [1]. Consumers' 
interest in goat milk and derived products is mainly related to its better digestibility for infants, the elderly and patients with gastrointestinal disorders [3,4] compared with cow milk; the smaller fat globule size and lower $\alpha \mathrm{s} 1$ casein content of goat compared with cow milk are the major reasons of the difference in digestibility and allergenicity [5,6]. Sanz Ceballos et al. [5] reported greater amounts of Ca, $\mathrm{P}, \mathrm{Mg}$ and $\mathrm{Cu}$ in goat compared with cow milk under identical environmental conditions. In addition, goat milk shows lower lactose content with a greater abundance of oligosaccharides derived from lactose, that positively affect human health for their prebiotic and anti-infective nature [7]. Moreover, goat milk contains more short fatty acids, n3, n6 and vitamin A than cow milk. Furthermore, fermented goat milk has a probiotic component that is maintained quite constant during the whole shelf life of the product for the low $\mathrm{pH}$ (6.47) and the buffering effect; in fact, fermented goat milk is considered a means to provide and improve probiotic intake in the human diet [7].

Milk minerals play an important role in human health [4,6] and milk coagulation ability [8]. In particular, $\mathrm{Ca}$ and $\mathrm{P}$ affect bone and teeth structure and muscular function, and $\mathrm{Zn}$ influences skin health and carbohydrate metabolism [6]. Copper and Fe are involved in the haemoglobin synthesis and transportation [9]. Moreover, Barrionuevo et al. [9] reported that goat milk consumption favoured $\mathrm{Fe}$ and $\mathrm{Cu}$ absorption in healthy rats and in those with malabsorption syndrome compared with cow milk. From a technological point of view, $\mathrm{Ca}$ and $\mathrm{P}$ strongly affect the milk coagulation ability and the firmness of the coagulum at the end of the coagulation process [8].

According to the literature, breed and stage of lactation affect mineral content of goat milk [10,11]. However, studies are mainly focused on cosmopolitan breeds such as Saanen, Toggenburg, Alpine and Anglo-Nubian [12,13], whereas local breeds are often neglected. In the last decades, local breeds have been progressively replaced with cosmopolitan breeds with the aim of increasing milk production. Nevertheless, studies on local breeds have revealed that milk gross composition is generally better in local than cosmopolitan breeds [12]. Moreover, the replacement of native with high productive breeds is responsible for the reduction of the variability within species, the loss of niche products related to specific breeds and the loss of historical heritage of the country [14]. The FAO database [15] reported that among the 55 Italian goat breeds, $61 \%$ are endangered and $29 \%$ are in unknown conditions of risk.

Nowadays, the assessment of milk quality is not only based on traditional components (i.e., fat and protein contents), but also on more specific compounds such as protein profile, fatty acid profile, and mineral content. However, information on those compounds and differences among breeds is very scarce. Due to the growing interest of consumers towards goat milk and dairy products, mineral and fatty acid composition of milk from local goat breeds might be useful to valorise their productions. Because some minerals are correlated with protein and fat content in milk [16], and differences in fat and protein content have been reported between Saanen and local breeds [12], we expect that breeds present differences in milk mineral content, in particular when local are compared with cosmopolitan breeds. Therefore, the aim of the present study was to characterise milk mineral contents of 5 local Italian goat breeds and to compare them with the cosmopolitan Saanen breed.

\section{Materials and Methods}

\subsection{Animals and Management Conditions}

This research was conducted from February to August 2016 in the experimental farm of the Council for Agricultural Research and Analysis of Agricultural Economy Analysis, Research Unit of Extensive Animal Production (CRA-ZOE, Potenza, Italy). Experimental procedures and animal care conditions followed the recommendations of European Union directive 86/609/EEC. All animals were in the same farm under the same management conditions. Breeds included in the study were Garganica (GA), Girgentana (GI), Jonica (JO), Maltese (MA), Mediterranean Red (MR) and Saanen (SA). A general description of the 6 breeds is reported in Currò et al. [17].

A total of 60 does (10 per breed) that kidded twins in February 2016 were enrolled in the study. Animals had similar body condition score at parturition (between 2.5 and 3.0; $1=$ very thin to $5=$ 
very fat, with 0.5 point-increment [18]), were from parity 1 to 5 (balanced among breeds) and their BW at the beginning of lactation averaged $48 \pm 4 \mathrm{~kg}$ for GA, $42 \pm 6 \mathrm{~kg}$ for GI, $47 \pm 6 \mathrm{~kg}$ for JO, $46 \pm$ $5 \mathrm{~kg}$ for MA, $48 \pm 3 \mathrm{~kg}$ for MR and $64 \pm 7 \mathrm{~kg}$ for SA. Kids were kept with their dams until 40 days after birth and temporarily separated $24 \mathrm{~h}$ before every sampling day. Does were milked twice a day (morning and evening) in a double 24-stall herringbone low-line milk pipeline milking parlour (Alfa Laval Agri; Monza, Italy) equipped with recording jars and electronic pulsators at a vacuum of $38 \mathrm{kPa}$, 90 pulses/min and $60 \%$ pulsation ratio. The pre-milking phase included only fore stripping without any preparation of udder and teats. None of the does presented mastitis events throughout the trial.

During the study, does grazed together during the day in a natural pasture (8h/day) and were supplemented with polyphite hay ad libitum in the shelter, composed of $60-65 \%$ of grasses (mainly Avena sativa L.) and 35-40\% of legumes (mainly Vicia sativa L.) [chemical composition: $89.10 \%$ of dry matter (DM), $15.10 \%$ of crude protein on DM, $52.60 \%$ of neutral detergent fibre on DM, and $1.10 \mathrm{Mcal} / \mathrm{kg}$ of net energy of lactation]. In addition, a commercial concentrate was offered to each doe in the milking parlour according to their requirements, considering the mean body weight and mean milk production every 15 days for each breed, following National Research Council recommendations [19]. Saanen received between 0.8 and $1.3 \mathrm{~kg} /$ day, and local breeds received between 0.5 and $1.0 \mathrm{~kg} /$ day, being the greatest amount at the beginning and the lowest at the end of the lactation. Throughout the study all goats consumed the total amount of concentrated offered, and no spillage was observed. Concentrate included maize, wheat bran and flour, maize and sunflower germ flours, sugar beet molasses, soybean meal ( $48 \%$ crude protein), calcium carbonate, sodium chloride, sodium bicarbonate, I ( $5 \mathrm{mg} / \mathrm{kg}$ ), Mn $(50 \mathrm{mg} / \mathrm{kg})$ and $\mathrm{Zn}(125 \mathrm{mg} / \mathrm{kg})$. The chemical composition of the commercial concentrate was $88.20 \%$ of DM, $21.70 \%$ of crude protein on DM, $23.00 \%$ of neutral detergent fibre on DM and $1.77 \mathrm{Mcal} / \mathrm{kg}$ of net energy of lactation.

\subsection{Sample Collection and Chemical Analysis}

Individual milk yield ( $\mathrm{kg} /$ day) was recorded for each doe as the sum of morning and evening milkings from 2 to 30 weeks of lactation using the recording jars in the milking parlour. A total of 840 individual milk samples $(50 \mathrm{~mL}$ each) were collected every two weeks and analysed for gross composition. Moreover, every month an additional milk sample from 42 out of the 60 goats $(50 \mathrm{~mL}$; $\mathrm{n}=252 ; 7$ goats per breed) was collected for mineral contents analysis.

Milk samples used for milk gross composition were stored at $4{ }^{\circ} \mathrm{C}$ and analysed in the milk laboratory of the Breeders Association of Basilicata region (Potenza, Italy). Fat-corrected milk at 3.5\% (FCM3.5\%, kg/day) was calculated according to Pulina et al. [20]:

$$
\text { FCM3.5\% = milk yield }(\mathrm{kg} / \text { day }) \times(0.634+0.1046 \times \text { fat } \%) .
$$

Fat, protein and lactose percentages were determined using MilkoScan FT6000 (Foss Electric, Hillerød, Denmark). Somatic cell count (SCC, cells/mL) was assessed by Fossomatic FC (Foss Electric,) and transformed to somatic cell score (SCS) through the following formula [21]:

$$
\mathrm{SCS}=3+\log 2(\mathrm{SCC} / 100000) \text {. }
$$

Milk samples used for minerals determination were stored at $-80^{\circ} \mathrm{C}$ and analysed in the laboratory of the Department of Agronomy, Food, Natural resources, Animals and Environment of the University of Padova (Legnaro, Italy). Major (K, Ca, $\mathrm{P}, \mathrm{Na}, \mathrm{S}$ and $\mathrm{Mg}$ ) and trace minerals ( $\mathrm{Zn}, \mathrm{B}, \mathrm{Sr}, \mathrm{Ba}, \mathrm{Fe}, \mathrm{Al}, \mathrm{As}, \mathrm{Cr}$, $\mathrm{Cu}$ and $\mathrm{Li}$ ) were determined using inductively coupled plasma optical emission spectrometry (ICP-OES), Ciros Vision EOP (Spectro Analytical Instruments GmbH, Kleve, Germany) after mineralisation of the sample with nitric acid in closed vessels by a microwave system (Ethos 1600 Milestone S.r.l., Sorisole, Italy), following the procedures described in Manuelian et al. [22]. Instrument operating parameters (sample aspiration rate of $2 \mathrm{~mL} / \mathrm{min}$, plasma power $1350 \mathrm{~W}$, coolant flow $11 \mathrm{~L} / \mathrm{min}$, auxiliary flow $0.60 \mathrm{~L} / \mathrm{min}$, nebulizer flow $0.75 \mathrm{~L} / \mathrm{min}$ and integration time of $28 \mathrm{~s}$ ) were optimized for acid solution. 
Calibration standards were prepared from single element solutions (Inorganic Ventures, Christiansburg, VA, USA) in a concentration range between 0 and $100 \mathrm{mg} / \mathrm{L}$ and matched with $5 \% \mathrm{HNO}_{3}$ (vol/vol) solution using 65\% $\mathrm{HNO}_{3}$ Suprapur (100441, Merck, Darmstadt, Germany). The wavelengths used to determine the minerals were: $766.941 \mathrm{~nm}$ for K, $317.933 \mathrm{~nm}$ for Ca, $178.287 \mathrm{~nm}$ for P, $589.592 \mathrm{~nm}$ for $\mathrm{Na}, 182.034 \mathrm{~nm}$ for S, $285.213 \mathrm{~nm}$ for $\mathrm{Mg}, 213.856 \mathrm{~nm}$ for Zn, $249.677 \mathrm{~nm}$ for B, 407.771 for Sr, 455.404 $\mathrm{nm}$ for Ba, $259.941 \mathrm{~nm}$ for Fe, $167.078 \mathrm{~nm}$ for Al, $189.042 \mathrm{~nm}$ for As, $267.716 \mathrm{~nm}$ for Cr, $324.754 \mathrm{~nm}$ for $\mathrm{Cu}$ and $670.780 \mathrm{~nm}$ for $\mathrm{Li}$. However, $\mathrm{Al}, \mathrm{As}, \mathrm{Cr}, \mathrm{Cu}$ and $\mathrm{Li}$ were below the limit of detection of the instrument $(0.01 \mu \mathrm{g} / \mathrm{kg}$ of DM) and were not further considered in this study.

\subsection{Statistical Analysis}

The final dataset consisted of 815 records for milk yield, FCM3.5\%, SCS and gross milk composition, and 217 records for milk mineral composition. Sources of variation of milk yield, FCM3.5\%, SCS, and gross and mineral composition were investigated using the MIXED procedure of SAS v9.4 (SAS Inst. Inc., Cary, NC, USA) with repeated measures, according to the following mixed linear model:

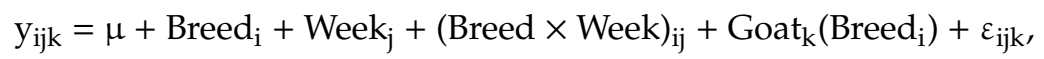

where $\mathrm{y}_{\mathrm{ijk}}$ is the dependent variable (milk yield, FCM3.5\%, SCS, fat, protein, lactose or each mineral); $\mu$ is the overall intercept of the model; Breed ${ }_{i}$ is the fixed effect of the $i$ th breed ( $i=$ GA, GI, JO, MA, MR, SA); Week $k_{j}$ is the fixed effect of the $j$ th week of lactation ( $j=1$ to 14 for milk yield, FCM3.5\%, SCS, fat, protein and lactose, corresponding to every 2 -week sampling; $j=1$ to 6 for each mineral, corresponding to every 4 -week sampling); (Breed $\times$ Week $)_{\mathrm{ij}}$ is the fixed interaction effect between breed and week of lactation; Goat ${ }_{\mathrm{k}}\left(\right.$ Breed $\left._{\mathrm{i}}\right)$ is the random effect of the $k$ th goat nested within the $i$ th breed $\sim \mathrm{N}$ $\left(0, \sigma^{2}\right.$ Goat(Breed) $)$; and $\varepsilon_{\mathrm{ijk}}$ is the random residual $\sim \mathrm{N}\left(0, \sigma_{\varepsilon}^{2}\right)$. In a preliminary analysis, the interactions Parity $\times$ Week of lactation and Breed $\times$ Parity were not significant and thus they were removed from the final model. Multiple comparisons of least squares means were performed for the main effects of breed and week of lactation using Tukey's test adjustment. Values are shown as least squares means \pm standard error and significance was declared at $p<0.05$, unless otherwise indicated.

\section{Results}

\subsection{Descriptive Statistics}

Descriptive statistics for milk yield, FCM3.5\%, SCS, fat, protein, lactose, major and trace minerals are reported in Table 1. Milk yield, SCS, fat, protein and lactose averaged $1.18 \mathrm{~kg} /$ day, 5.61 units, 3.97\%, $3.36 \%$ and $4.48 \%$, respectively. As expected, milk yield and FCM3.5\% were the most variable traits [coefficient of variation $(\mathrm{CV})=45 \%$ and $41 \%$, respectively] followed by SCS $(\mathrm{CV}=34 \%)$. A lower variation was observed for fat $(\mathrm{CV}=27 \%)$, protein $(\mathrm{CV}=17 \%)$ and lactose $(\mathrm{CV}=7 \%)$.

The most abundant mineral in goat milk was K $(1662 \mathrm{mg} / \mathrm{kg})$ followed by Ca $(1067 \mathrm{mg} / \mathrm{kg})$ and P (796 mg/kg; Table 1). The other major minerals had an overall concentration between $107 \mathrm{mg} / \mathrm{kg}(\mathrm{Mg})$ and $348 \mathrm{mg} / \mathrm{kg}$ (Na; Table 1). Among trace minerals, the most abundant was $\mathrm{Zn}(2.70 \mu \mathrm{g} / \mathrm{g})$ followed by $B(1.42 \mu \mathrm{g} / \mathrm{g})$. The other trace minerals ranged from an overall mean of $0.31 \mu \mathrm{g} / \mathrm{g}(\mathrm{Fe})$ to $0.81 \mu \mathrm{g} / \mathrm{g}$ (Sr). The CV was lower for major than trace minerals: in particular, the CV of major minerals ranged from $14 \%(\mathrm{~K})$ to $20 \%$ (Na and $\mathrm{Mg}$ ), and CV of trace minerals from $27 \%(\mathrm{Zn})$ to $91 \%(\mathrm{Ba})$. 
Table 1. Descriptive statistics of goat milk yield, composition and mineral contents.

\begin{tabular}{|c|c|c|c|c|c|}
\hline Trait & N. of Observation & Mean & SD & Minimum & Maximum \\
\hline $\begin{array}{l}\text { Milk yield } \\
\text { (kg/day) }\end{array}$ & 815 & 1.18 & 0.53 & 0.20 & 3.25 \\
\hline $\begin{array}{l}\text { FCM3.5\% } \\
(\mathrm{kg} / \text { day })^{1}\end{array}$ & 815 & 1.21 & 0.50 & 0.22 & 3.18 \\
\hline Fat $(\%)$ & 815 & 3.97 & 1.06 & 1.90 & 8.81 \\
\hline Protein (\%) & 815 & 3.36 & 0.56 & 2.10 & 5.61 \\
\hline Lactose (\%) & 815 & 4.48 & 0.33 & 3.30 & 5.41 \\
\hline SCS (units) ${ }^{2}$ & 815 & 5.61 & 1.90 & 0.36 & 10.17 \\
\hline \multicolumn{6}{|c|}{ Major minerals (mg/kg) } \\
\hline $\mathrm{K}$ & 217 & 1662 & 231 & 1117 & 2278 \\
\hline $\mathrm{Ca}$ & 217 & 1067 & 193 & 480 & 1593 \\
\hline $\mathrm{P}$ & 217 & 796 & 127 & 462 & 1122 \\
\hline $\mathrm{Na}$ & 217 & 348 & 71 & 241 & 650 \\
\hline S & 217 & 293 & 50 & 150 & 411 \\
\hline $\mathrm{Mg}$ & 217 & 107 & 22 & 64 & 169 \\
\hline \multicolumn{6}{|c|}{ Trace elements $(\mu \mathrm{g} / \mathrm{g})$} \\
\hline $\mathrm{Zn}$ & 217 & 2.70 & 0.74 & 0.67 & 4.74 \\
\hline B & 217 & 1.42 & 0.80 & 0.04 & 3.71 \\
\hline $\mathrm{Sr}$ & 217 & 0.81 & 0.28 & 0.05 & 1.52 \\
\hline $\mathrm{Ba}$ & 217 & 0.35 & 0.32 & 0.06 & 1.92 \\
\hline $\mathrm{Fe}$ & 217 & 0.31 & 0.16 & 0.06 & 0.98 \\
\hline
\end{tabular}

${ }^{1}$ FCM3.5\% = milk yield $(\mathrm{kg} /$ day $) \times(0.634+0.1046 \times$ fat $\%) ;{ }^{2} \mathrm{SCS}=3+\log _{2}(\mathrm{SCC} / 100000)$.

\subsection{Breed Effect}

Breed strongly affected milk yield, FCM3.5\%, fat, protein, lactose and SCS ( $p<0.01$; Table 2). Saanen had greater milk yield and SCS but lower fat content compared with the local breeds. However, in terms of FCM3.5\% SA had similar milk production than JO and MA. Moreover, milk protein content of SA differed only from MA, and lactose content was similar between the SA and the GA. The order of abundance of major and trace minerals was similar in the different breeds (Table 2). Also, mineral contents slightly differed among breeds, and differences concerned only $\mathrm{P}(p<0.001), \operatorname{Mg}(p=0.048)$ and $\mathrm{Zn}(p<0.001)$. The greatest $\mathrm{P}$ content was detected for MR and JO, whose milk had on average $121 \mathrm{mg} / \mathrm{kg}$ more P than MA and GI breeds $(p<0.001)$. No differences between SA and the local breeds were observed for P. Regarding Mg content, the only significant difference was observed between SA and MA $(+25 \mathrm{mg} / \mathrm{kg}$ for SA; $p<0.05)$. Mediterranean Red and JO breeds had the greatest $\mathrm{Zn}$ content, producing about $0.90,0.72$ and $0.69 \mu \mathrm{g} / \mathrm{g}$ more $\mathrm{Zn}$ than MA, GI and SA breeds, respectively. 
Table 2. Least squares means of milk yield, composition and mineral contents of 6 goat breeds.

\begin{tabular}{|c|c|c|c|c|c|c|c|c|}
\hline \multirow{2}{*}{ Traits } & \multicolumn{6}{|c|}{ Breed $^{1}$} & \multicolumn{2}{|c|}{ Overall } \\
\hline & GA & GI & JO & MA & MR & SA & SEM & $p$ \\
\hline Milk yield (kg/day) & $0.99^{d}$ & $0.93^{d}$ & $1.25^{\mathrm{bc}}$ & $1.28^{\mathrm{b}}$ & $1.01^{\mathrm{cd}}$ & $1.55^{\mathrm{a}}$ & 0.10 & $* * *$ \\
\hline FCM $3.5 \%(\mathrm{~kg} / \text { day })^{2}$ & $1.01^{\mathrm{b}}$ & $1.00^{\mathrm{b}}$ & $1.30^{\mathrm{a}}$ & $1.33^{\mathrm{a}}$ & $1.05^{\mathrm{b}}$ & $1.50^{\mathrm{a}}$ & 0.08 & $* * *$ \\
\hline Fat (\%) & $3.90^{\mathrm{a}}$ & $4.42^{\mathrm{a}}$ & $4.10^{\mathrm{a}}$ & $4.04^{\mathrm{a}}$ & $4.13^{\mathrm{a}}$ & $3.26^{\mathrm{b}}$ & 0.16 & $* * *$ \\
\hline Protein (\%) & $3.71^{\mathrm{a}}$ & $3.27^{b c}$ & $3.36^{\mathrm{bc}}$ & $3.11^{\mathrm{c}}$ & $3.40^{\mathrm{b}}$ & $3.42^{\mathrm{ab}}$ & 0.08 & $* * *$ \\
\hline Lactose (\%) & $4.26^{\mathrm{b}}$ & $4.47^{\mathrm{a}}$ & $4.53^{\mathrm{a}}$ & $4.49^{\mathrm{a}}$ & $4.58^{\mathrm{a}}$ & $4.28^{\mathrm{b}}$ & 0.04 & $* * *$ \\
\hline SCS (units) $)^{3}$ & $5.90^{\mathrm{b}}$ & $5.05^{\mathrm{c}}$ & $5.54^{\mathrm{bc}}$ & $5.04^{\mathrm{C}}$ & $5.46^{\mathrm{bc}}$ & $6.78^{\mathrm{a}}$ & 0.27 & $* * *$ \\
\hline \multicolumn{9}{|c|}{ Major minerals (mg/kg) } \\
\hline $\mathrm{K}$ & 1753 & 1753 & 1605 & 1587 & 1585 & 1667 & 32 & \\
\hline $\mathrm{Ca}$ & 1073 & 975 & 1144 & 1041 & 1100 & 1093 & 24 & \\
\hline $\mathrm{P}$ & $784^{\mathrm{ab}}$ & $756^{\mathrm{b}}$ & $833^{\mathrm{a}}$ & $716^{\mathrm{b}}$ & $882^{\mathrm{a}}$ & $817^{\mathrm{ab}}$ & 24 & $* * *$ \\
\hline $\mathrm{Na}$ & 374 & 332 & 353 & 340 & 326 & 359 & 7 & \\
\hline$S$ & 305 & 277 & 302 & 277 & 308 & 288 & 6 & \\
\hline $\mathrm{Mg}$ & $114^{\mathrm{ab}}$ & $102^{\mathrm{ab}}$ & $107^{\mathrm{ab}}$ & $95^{\mathrm{b}}$ & $111^{\mathrm{ab}}$ & $120^{\mathrm{a}}$ & 4 & * \\
\hline \multicolumn{9}{|l|}{ Trace elements $(\mu \mathrm{g} / \mathrm{g})$} \\
\hline $\mathrm{Zn}$ & $2.65^{\mathrm{ab}}$ & $2.46^{\mathrm{b}}$ & $3.17^{\mathrm{a}}$ & $2.29^{b}$ & $3.19^{\mathrm{a}}$ & $2.49^{\mathrm{b}}$ & 0.16 & **** \\
\hline $\mathrm{B}$ & 1.32 & 1.33 & 1.36 & 1.57 & 1.32 & 1.56 & 0.05 & \\
\hline $\mathrm{Sr}$ & 0.75 & 0.75 & 0.97 & 0.80 & 0.80 & 0.80 & 0.03 & \\
\hline $\mathrm{Ba}$ & 0.25 & 0.35 & 0.42 & 0.24 & 0.36 & 0.40 & 0.03 & \\
\hline $\mathrm{Fe}$ & 0.33 & 0.31 & 0.30 & 0.27 & 0.33 & 0.35 & 0.04 & \\
\hline
\end{tabular}

${ }^{1} \mathrm{GA}=$ Garganica; $\mathrm{GI}=$ Girgentana; $\mathrm{JO}=$ Jonica; MA = Maltese; MR = Mediterranean Red; SA = Saanen; ${ }^{2}$ FCM3.5\% $=$ milk yield $(\mathrm{kg} /$ day $) \times(0.634+0.1046 \times$ fat $\%) ;{ }^{3} \mathrm{SCS}=3+\log 2(\mathrm{SCC} / 100000) ;$ abc Least squares means with different superscripts within a row differ significantly $(p<0.05){ }^{*} p<0.05,{ }^{* *} p<0.01,{ }^{* * *} p<0.001$.

\subsection{Effect of Stage of Lactation}

Week of lactation affected $(p<0.001)$ milk yield, FCM3.5\%, fat, protein, lactose and SCS. Milk yield, FCM $3.5 \%$ and lactose decreased by $67 \%, 63 \%$ and $11 \%$, respectively, across lactation, whereas SCS, fat and protein increased by $60 \%, 44 \%$ and $37 \%$, respectively. Week of lactation affected also major and trace minerals $(p<0.001 ; p=0.023$ for $\mathrm{Zn})$ with the exception of $\mathrm{B}(p=0.83)$. The lowest milk contents of K (1500 mg/kg), Ca (989 mg/kg), P (747 mg/kg), Na (304 mg/kg), S (256 mg/kg) and $\mathrm{Mg}(96 \mathrm{mg} / \mathrm{kg}$ ) were observed in early lactation (4th and 8th week of lactation), which corresponded to the peak of lactation (Figure 1). In particular, the lowest K amount was detected in the 4th week of lactation $(1500 \mathrm{mg} / \mathrm{kg})$, whereas its amount increased in the 8th week of lactation $(+12.9 \%)$ and remained stable until the end of lactation. Conversely to $\mathrm{K}$ trend, the content of $\mathrm{Ca}, \mathrm{P}$ and $\mathrm{Na}$ was quite stable from 4 th to 16 th week of lactation, incremented $+10 \%$ for $\mathrm{Ca}$ and $\mathrm{P}$ and $15 \%$ for $\mathrm{Na}$ between the 16th and late lactation (20th and 24th week of lactation). Moreover, $\mathrm{S}$ and $\mathrm{Mg}$ showed the lowest content in early lactation and increased of $15 \%$ during mid lactation (12th and 16th week of lactation) reporting the greatest content (Ca, $1156 \mathrm{mg} / \mathrm{kg} ; \mathrm{P}, 889 \mathrm{mg} / \mathrm{kg} ; \mathrm{Na}, 404 \mathrm{mg} / \mathrm{kg} ; \mathrm{S}, 329 \mathrm{mg} / \mathrm{kg}$; $\mathrm{Mg}, 122 \mathrm{mg} / \mathrm{kg}$ ) in late lactation (20th and 24th week of lactation). The greatest $\mathrm{Zn}$ content was found at the 4 th week of lactation $(2.94 \mu \mathrm{g} / \mathrm{g})$, which differed significantly from the 8th week of lactation $(2.47 \mu \mathrm{g} / \mathrm{g})$. Intermediate values of $\mathrm{Zn}$ content were observed from the 12th to 24th week of lactation ( 2.64 to $2.80 \mu \mathrm{g} / \mathrm{g})$. Strontium showed the greatest content in early lactation $(1.00 \mu \mathrm{g} / \mathrm{g}$ from the 4 th to 8th week of lactation), decreased by $37 \%$ until the 16 th week $(0.63 \mu \mathrm{g} / \mathrm{g})$ and increased thereafter again until the 24 th week of lactation $(0.83 \mu \mathrm{g} / \mathrm{g})$. 
a)

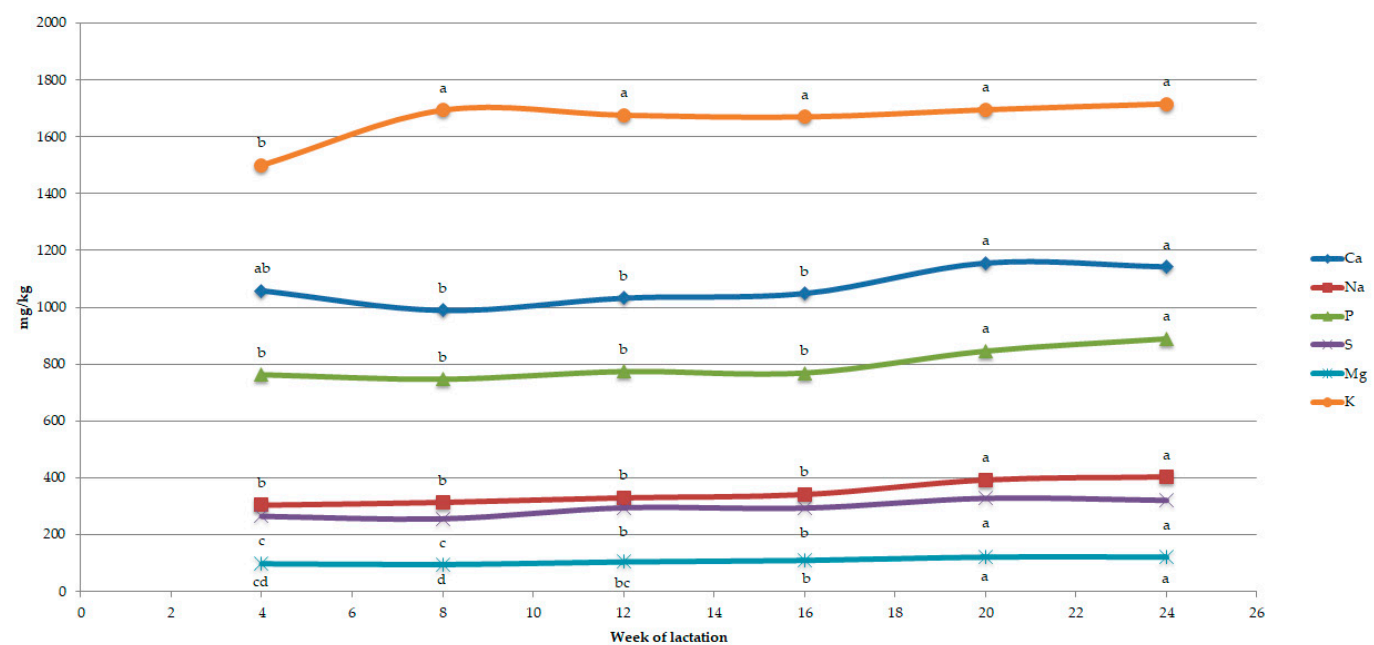

b)

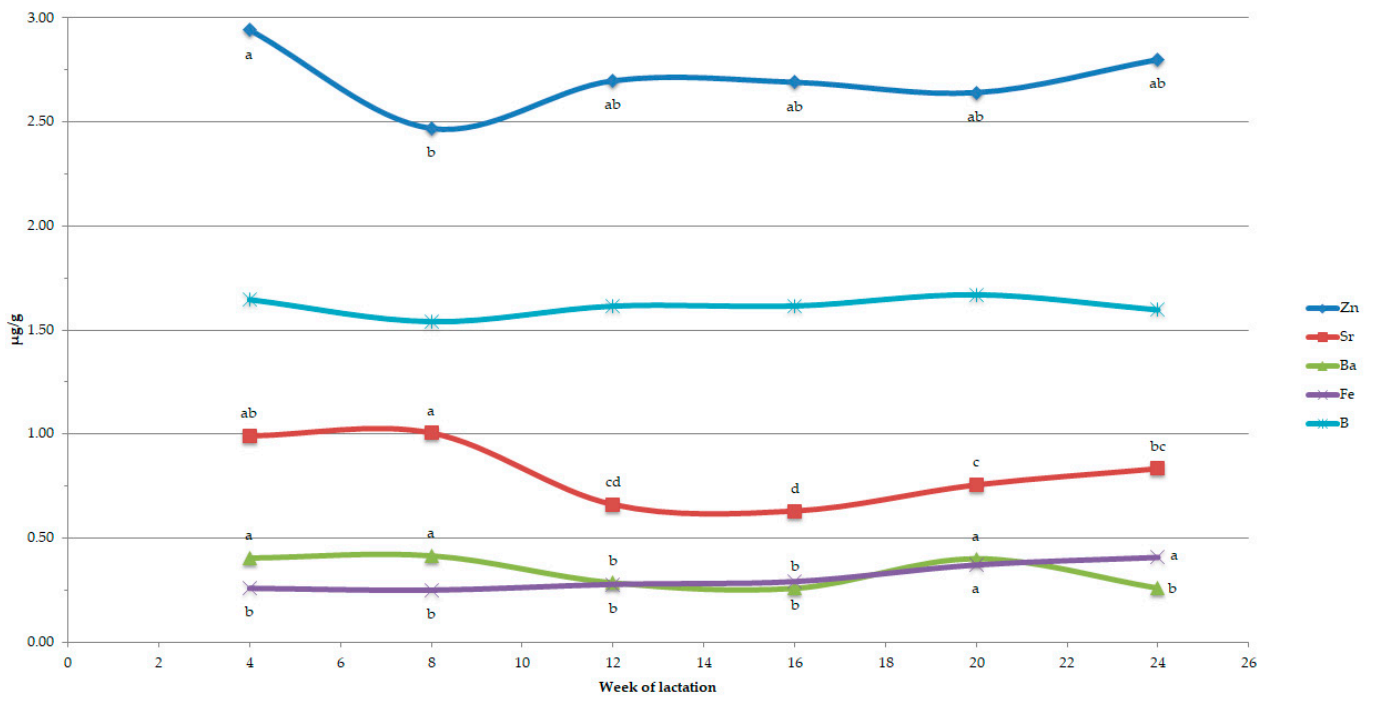

Figure 1. Least squares means of (a) major and (b) trace minerals of goat milk during lactation. Least squares means with different superscripts within a mineral differ significantly $(p<0.05)$.

Barium showed an erratic pattern throughout lactation: the greatest values were obtained in early (4th and 8th week of lactation) and in the 20th week of lactation $(0.40 \mu \mathrm{g} / \mathrm{g})$, whereas the lowest were observed in mid (12th and 16th week of lactation) and in the 24 th week of lactation $(0.27 \mu \mathrm{g} / \mathrm{g})$. Iron showed the lowest amount between the 4th and 16th week of lactation and increased in late lactation, where it reached the greatest content $(0.39 \mu \mathrm{g} / \mathrm{g})$.

\section{Discussion}

\subsection{Means and Variation of Milk Gross Composition and Mineral Content}

Overall, means of milk yield and fat, protein and lactose contents were consistent with values of goat milk production and composition reported by Muehlhoff [23]. The average SCS observed in our study (SCS $=5.61$ ) was similar to that reported by Niero et al. [24] for goat milk $(\mathrm{SCS}=5.74)$. The greatest variability of milk yield was expected because the present study dealt with milk samples collected across a complete lactation and included several breeds. The variation observed for FCM3.5\% $(\mathrm{CV}=41 \%)$ was greater than the one reported by Bonanno et al. [25] for GI (CV $=29 \%)$ when evaluating the feed effect on 37 goats during 3 months (from April to May). The variability of SCS (CV = 34\%) was in agreement with Vacca et al. [26], who reported a similar variation in individual milk samples of six 
goat breeds (SA, Camosciata delle Alpi, Murciano-Granadina, MA, Sarda and Sarda primitive). Also, the variability observed for fat, protein and lactose contents agreed with findings of Niero et al. [24].

Regarding milk minerals, the greater content of $\mathrm{K}$ and Ca compared with other minerals in goat milk was in agreement with Kondyli et al. [3] in local Greek goats and StrzaŁkowska et al. [27] in Polish White improved goats. Nevertheless, Park and Chukwu [11] reported greater content of P (1410 $\mathrm{mg} / \mathrm{L})$ than $\mathrm{Ca}(1389 \mathrm{ml} / \mathrm{L})$ and K $(989 \mathrm{mg} / \mathrm{L})$ in milk of French Alpine and Anglo-Nubian goat breeds during the first 5 months of lactation. Milk of local goats of Canary Island [28] had greater Ca (1340 $\mathrm{mg} / \mathrm{kg}), \mathrm{Na}(510 \mathrm{mg} / \mathrm{kg})$ and $\mathrm{Mg}$ contents $(120 \mathrm{mg} / \mathrm{kg})$ and lower K content $(1240 \mathrm{mg} / \mathrm{kg})$ compared with the present study. The variability observed for K, P and Ca in our study was similar to the CV reported by StrzaŁkowska et al. [27] in Polish White improved goats. On the other hand, the variability reported by García et al. [28] for $\mathrm{Ca}(\mathrm{CV}=18 \%)$ and $\mathrm{K}(\mathrm{CV}=16 \%)$ was similar to the $\mathrm{CV}$ reported in the present study, whereas they observed a greater variability for $\mathrm{Mg}(\mathrm{CV}=25 \%)$.

Regarding trace element, the overall Zn content was lower than Zn contents reported by García et al. [28] (3.20 $\mu \mathrm{g} / \mathrm{g})$, Kondyli et al. [3] $(3.80 \mu \mathrm{g} / \mathrm{g})$ and Güler [29] (4.68 $\mu \mathrm{g} / \mathrm{g})$, and the B content was lower than that reported by Güler [29] $(16.9 \mu \mathrm{g} / \mathrm{g})$, and Şanal et al. [30] $(8.09 \mu \mathrm{g} / \mathrm{g})$ in a Turkish's local goat breed. The lower contents of B, Sr, Ba and Fe in the present study compared with Güler [29] (16.9, $1.10,0.99$ and $3.88 \mu \mathrm{g} / \mathrm{g}$, respectively) could be related to the period of lactation considered; indeed, we studied the complete lactation whereas Güler [29] considered milk from late lactation, where milk yield decreases and milk components become more concentrated.

\subsection{Breed Effect on Milk Mineral Content}

The differences of milk gross composition among breeds have been previously discussed in Currò et al. [17]. Very few studies have assessed the mineral composition of goat milk and the differences among breeds. In fact, milk from Anglo-Nubian and French Alpine goats differed in $\mathrm{Na}$ and $\mathrm{K}$ content [11]. Trancoso et al. [12] found breed differences for $\mathrm{Ca}, \mathrm{P}, \mathrm{Mg}, \mathrm{Na}, \mathrm{K}$ and Fe among several Portuguese breeds (Serrana, Serpentina, Charnequeira and Algarvia) and SA reared in different regions. Moreover, those authors observed significant differences between the two different ecotypes (Trasmontana and Ribatejana) of Serrana breed, which suggested that those differences were likely related to the feeding. On the other hand, Mestawet et al. [13] did not observe significant variation for $\mathrm{Ca}, \mathrm{P}, \mathrm{K}, \mathrm{Mg}, \mathrm{Na}$, Zn and Fe content among four Ethiopian goat genotypes (Somali, Arsi-Bale, Boer and Toggenburg $\times$ Arsi-bale crossbred). A greater content of $\mathrm{P}$ and $\mathrm{Mg}$ in milk (being part of the casein micelles) could indicate better milk coagulation capacity [31]. However, to compare milk minerals content among studies, differences in botanical species of grazing area, feeding strategies and drinking water composition [32], and the different analytical methods used in each study should be considered because they have an impact on milk mineral contents [33].

\subsection{Effect of Stage of Lactation on Milk Mineral Content}

The differences of milk gross composition among week of lactation have been previously discussed in Currò et al. [17]. The effect of week of lactation on mineral profile in goat milk has been reported by other authors. Nevertheless, the pattern described in the present study for K was opposite compared with findings of Park and Chukwu [11]. Those authors observed the greatest $\mathrm{K}$ amount at the 4 th week of lactation for Anglo-Nubian goats $(1322 \mathrm{mg} / \mathrm{L})$ and at the 8 th week of lactation for French Alpine goats $(1505 \mathrm{mg} / \mathrm{L})$, with decreasing values thereafter until the 21 st week of lactation $(530 \mathrm{mg} / \mathrm{L}$ at and $675 \mathrm{mg} / \mathrm{L}$, respectively). A possible reason to explain differences in the described pattern for $\mathrm{K}$ content between our study and Park and Chukwu [11] could be the ad libitum access to a ration rich in $\mathrm{K}(1.82 \%$ of $\mathrm{DM})$ until the 12 th week of lactation in the latter study. On the other hand, the pattern observed for $\mathrm{Ca}, \mathrm{P}, \mathrm{Na}, \mathrm{S}$ and $\mathrm{Mg}$ in the present study agreed with results described in Ethiopian goat breeds by Mestawet et al. [13]. Antunović et al. [34] and Park and Chukwu [11] detected the greatest Ca content at the end of the lactation in Croatian $(1589 \mathrm{mg} / \mathrm{kg})$ and Anglo-Nubian $(1538 \mathrm{mg} / \mathrm{kg}) \mathrm{goat}$ breeds, respectivily. 
Zinc trend reported in our study was in agreement with Antunović et al. [34] who reported the lowest $\mathrm{Zn}$ content $(2.40 \mu \mathrm{g} / \mathrm{g})$ at the 8 th week of lactation and an increment thereafter until the 21st week of lactation $(3.60 \mu \mathrm{g} / \mathrm{g})$ in Croatian goats. However, a different trend for $\mathrm{Zn}$ was reported by Kondyli et al. [3] in Greek local goats with a grazing period from April to July. Those authors observed the greatest $\mathrm{Zn}$ content at the 6 th week of lactation $(4.6 \mu \mathrm{g} / \mathrm{g})$ and the lowest at the end of lactation $(3.1 \mu \mathrm{g} / \mathrm{g})$. Contrary to the pattern of Fe described in the present study, Kondyli et al. [3] and Antunović et al. [34] reported a stable Fe content in milk through the whole lactation in Greek and Croatian goats, respectively. In addition, StrzaŁkowska et al. [27] observed in White Polish goats an erratic trend of milk Fe content through lactation with maximum values in the 1st, 7 th and 10th weeks of lactation $(1.21 \mu \mathrm{g} / \mathrm{mL})$ and the lowest contents at the 24th week of lactation $(1.04 \mu \mathrm{g} / \mathrm{mL})$. To the best of our knowledge, this is the first study investigating $\mathrm{Sr}$ and Ba milk content variation through lactation and for this reason comparison with other studies dealing with this topic is not possible.

The increase of major mineral contents in milk through lactation could be the consequence of the concentration effect due to low milk yield at the end of lactation [35]. However, the greater concentration of minerals at the end than at the beginning of lactation could also depend on extrinsic factors such as seasonal conditions (temperature and rainfall), soil and phenological state of plant as reported by Qeshlagh et al. [36] who detected greater $\mathrm{Ca}, \mathrm{P}$ and $\mathrm{Na}$ contents in ewe milk in summer than spring grazing season. The greatest $B$ sources are food and drinking water [32]. In this study, the $\mathrm{B}$ content fluctuate across lactation. The greater mineral content in late lactation could result in better milk coagulation properties than in early lactation; indeed, Malacarne et al. [31] affirmed that milk richer in $\mathrm{Ca}, \mathrm{P}$ and $\mathrm{Mg}$ influence positively milk coagulation properties (low rennet coagulation time and curding firming time with great curd firmness) in agreement with Vacca et al. [26] who found that goat milk at the end of lactation showed better rennet coagulation time, shorter curd-firming time and a greater curd firmness compared with milk at the beginning of lactation.

\section{Conclusions}

The results of the present study contribute to the characterisation of milk from Italian local goat breeds with regards to mineral content and compare the milk mineral profiles of local breeds and the cosmopolitan Saanen breed. Small differences among breeds were observed for major and trace minerals in milk, being significant only for $\mathrm{P}, \mathrm{Mg}$ and $\mathrm{Zn}$. Although SA yielded more milk with greater SCS and lower fat concentration than the local breeds, this breed had the same P, Mg and Zn milk content than local breeds. Week of lactation affected significantly all major and trace minerals in milk (except for B), and the greatest contents for almost all the minerals were observed at the end of lactation, likely due to a concentration effect. Mineral fraction in milk is important for a technological point of view as well as for human health, thus the characterisation of the mineral profile of local goat breeds is a possible strategy to valorise the autochthonous breeds and preserve the biodiversity.

Author Contributions: S.C. (Sarah Currò) performed the mineral analysis, the statistical analyses and drafted the manuscript. C.L.M. and M.D.M. were involved in drafting the paper and in the statistical analyses. M.D.M. funded the milk mineral analyses. S.C. (Salvatore Claps) were responsible of the animal management and sample collection. G.N., P.D.P. and A.S. designed the research. All authors contributed to the discussion of the results and approved the final draft of the manuscript.

Funding: This research received no external funding.

Acknowledgments: We are grateful to Professor Mauro Penasa of the University of Padova for helping with the statistical analysis and revising the manuscript.

Conflicts of Interest: The authors declare no conflict of interest.

\section{References}

1. FAOSTAT; The Food and Agriculture Organization Corporate Statistical Database. Available online: www.fao.org/faostat/en/ (accessed on 21 June 2019). 
2. Boyazoglu, J.; Morand-Fehr, P. Mediterranean dairy sheep and goat products and their quality A critical review. Small Rumin. Res. 2001, 40, 1-11. [CrossRef]

3. Kondyli, E.; Katsiari, M.C.; Voutsinas, L.P. Variations of vitamin and mineral contents in raw goat milk of the indigenous Greek breed during lactation. Food Chem. 2007, 100, 226-230. [CrossRef]

4. Kumar, H.; Yadav, D.; Kumar, N.; Seth, R.; Goyal, A.K. Nutritional and nutraceutical properties of goat milk a review. Indian J. Dairy Sci. 2016, 69, 513-518.

5. Sanz Ceballos, L.; Morales, E.R.; De La, G.; Adarve, T.; Castro, J.D.; Pé Rez Martínez, L.; Remedios, M.; Sampelayo, S. Composition of goat and cow milk produced under similar conditions and analyzed by identical methodology. J. Food Compos. Anal. 2009, 22, 322-329. [CrossRef]

6. Zenebe, T.; Ahmed, N.; Kabeta, T.; Kebede, G. Review on Medicinal and Nutritional Values of Goat Milk. Acad. J. Nutr. 2014, 3, 30-39.

7. Ranadheera, C.S.; Evans, C.A.; Baines, S.K.; Balthazar, C.F.; Cruz, A.G.; Esmerino, E.A.; Freitas, M.Q.; Pimentel, T.C.; Wittwer, A.E.; Naumovski, N.; et al. Probiotics in goat milk products: Delivery capacity and ability to improve sensory attributes. Compr. Rev. Food Sci. Food Saf. 2019, 00, 1-16. [CrossRef]

8. Lucey, J.A.; Fox, P.F. Importance of calcium and phosphate in cheese manufacture: A Review. J. Dairy Sci. 1993, 76, 1714-1724. [CrossRef]

9. Barrionuevo, M.; Alferez, M.J.M.; Lopez Aliaga, I.; Sanz Sampelayo, M.R.; Campos, M.S. Beneficial effect of goat milk on nutritive utilization of iron and copper in malabsorption syndrome. J. Dairy Sci. 2002, 85, 657-664. [CrossRef]

10. Khan, Z.I.; Ashraf, M.; Hussain, A.; McDowell, L.R.; Ashraf, M.Y. Concentrations of minerals in milk of sheep and goats grazing similar pastures in a semiarid region of Pakistan. Small Rumin. Res. 2006, 65, 274-278. [CrossRef]

11. Park, Y.W.; Chukwu, H.I. Macro-Mineral concentrations in milk of two goat breeds at different stages of lactation. Small Rumin. Res. 1988, 1, 157-166. [CrossRef]

12. Trancoso, I.M.; Trancoso, M.A.; Martins, A.P.L.; Roseiro, L.B. Chemical composition and mineral content of goat milk from four indigenous Portuguese breeds in relation to one foreign breed. Int. J. Dairy Technol. 2010, 63, 516-522. [CrossRef]

13. Mestawet, T.A.; Girma, A.; Ådnøy, T.; Devold, T.G.; Narvhus, J.A.; Vegarud, G.E. Milk production, composition and variation at different lactation stages of four goat breeds in Ethiopia. Small Rumin. Res. 2012, 105, 176-181. [CrossRef]

14. Gandini, G.C.; Villa, E. Analysis of the cultural value of local livestock breeds: a methodology. J. Anim. Breed. Genet. 2003, 120, 1-11. [CrossRef]

15. DAD-IS Domestic Animal Diversity Information System (DAD-IS). Available online: http://dad.fao.org/ (accessed on 22 March 2019).

16. Park, Y.W. Nutrient and mineral composition of commercial US goat milk yogurts. Small Rumin. Res. 1994, 13, 63-70. [CrossRef]

17. Currò, S.; Manuelian, C.L.; De Marchi, M.; De Palo, P.; Claps, S.; Maggiolino, A.; Campanile, G.; Rufrano, D.; Fontana, A.; Pedota, G.; et al. Autochthonous dairy goat breeds showed better milk quality than Saanen under the same environmental conditions. Arch. Anim. Breed. 2019, 62, 83-89. [CrossRef]

18. Villaquiran, M.; Gipson, T.A.; Merkel, R.; Goetsch, A.; Sahlu, T. Body Condition Scoring for Improved Management. In Proceedings of the 20th Annual Goat Field Day, Langston University, Langston, Oklahoma, 30 April 2005.

19. National Research Council. Nutrient Requirements of Small Ruminants: Sheep, Goats, Cervids, and New World Camelids, 6th ed.; The National Academies Press: Washington DC, USA, 2007.

20. Pulina, G.; Cannas, A.; Serra, A.; Vallebella, R. Determination and estimation of the energy value in Sardinian goat milk. In Proceedings of the Congress of Società Italiana Scienze Veterinarie (SISVet), Altavilla Milicia (PA), Italy, 25-28 September 1991; pp. 1779-1781.

21. Wiggans, G.R.; Shook, G.E. A lactation measure of somatic cell count. J. Dairy Sci. 1987, 70, $2666-2672$. [CrossRef]

22. Manuelian, C.; Currò, S.; Penasa, M.; Cassandro, M.; De Marchi, M. Characterization of major and trace minerals, fatty acid composition, and cholesterol content of Protected Designation of Origin cheeses. J. Dairy Sci. 2017, 100, 3384-3395. [CrossRef] 
23. Food and Agriculture Organization of the United Nations (FAO). Milk and dairy products in human nutrition. In Milk and Dairy Products in Human Nutrition; FAO: Rome, Italy, 2013; pp. 1-376.

24. Niero, G.; Currò, S.; Costa, A.; Penasa, M.; Cassandro, M.; Boselli, C.; Giangolini, G.; De Marchi, M. Short communication: Phenotypic characterization of total antioxidant activity of buffalo, goat, and sheep milk. J. Dairy Sci. 2018, 101, 4864-4868. [CrossRef]

25. Bonanno, A.; Todaro, M.; Di Grigoli, A.; Scatassa, M.L.; Tornambè, G.; Alicata, M.L. Relationships between dietary factors and milk urea nitrogen level in goats grazing herbaceous pasture. Ital. J. Anim. Sci. 2008, 7, 219-235. [CrossRef]

26. Vacca, G.M.; Stocco, G.; Dettori, M.L.; Pira, E.; Pazzola, M.; Bittante, G. Milk yield, quality, and coagulation properties of 6 breeds of goats: Environmental and individual variability. J. Dairy Sci. 2018, 101, 7236-7247. [CrossRef]

27. Strzałkowska, N.; Bagnicka, E.; Jóźwik, A.; Krzyzewski, J. Macro- and micro-elements' concentration in goat milk during lactation. Zuchtungskunde 2008, 80, 404-411.

28. García, M.I.H.; Puerto, P.P.; Baquero, M.F.; Rodríguez, E.R.; Martín, J.D.; Romero, C.D. Mineral and trace element concentrations of dairy products from goats' milk produced in Tenerife (Canary Islands). Int. Dairy J. 2006, 16, 182-185. [CrossRef]

29. Güler, Z. Levels of 24 minerals in local goat milk, its strained yoghurt and salted yoghurt (tuzlu yŏgurt). Small Rumin. Res. 2007, 71, 130-137. [CrossRef]

30. Şanal, H.; Güler, Z.; Park, Y.W. Profiles of non-essential trace elements in ewe and goat milk and their yoghurt, torba yoghurt and whey. Food Addit. Contam. Part B 2011, 4, 275-281.

31. Malacarne, M.; Franceschi, P.; Formaggioni, P.; Sandri, S.; Mariani, P.; Summer, A. Influence of micellar calcium and phosphorus on rennet coagulation properties of cows milk. J. Dairy Res. 2014, 81, 129-136. [CrossRef]

32. Diana, G.; Beni, C.; Marconi, S. Bovine milk chain in Italian farms. II. Boron levels in soil, gravitational and clean water, bovine diet, and milk. Agrochimica 2009, 53, 25-40.

33. Lante, A.; Lomolino, G.; Cagnin, M.; Spettoli, P. Content and characterisation of minerals in milk and in Crescenza and Squacquerone Italian fresh cheeses by ICP-OES. Food Control 2006, 17, 229-233. [CrossRef]

34. Antunović, Z.; Marić, I.; Lončarić, Z.; Novoselec, J.; Mioč, B.; Klir, Ž. Changes in macroelements, trace elements, heavy metal concentrations and chemical composition in milk of Croatian spotted goats during different lactation stages. Int. J. Dairy Technol. 2018, 71, 621-628. [CrossRef]

35. Albenzio, M.; Santillo, A.; Caroprese, M.; Ciliberti, M.; Marino, R.; Sevi, A. Effect of stage of lactation on the immune competence of goat mammary gland. J. Dairy Sci. 2016, 99, 3889-3895. [CrossRef]

36. Qeshlagh, F.M.A.; Yonjalli, R.V.; Ghorbani, A.; Achachlouei, B.F. Milk composition and mineral concentration affected by elevation and grazing season in the Rangelands of North Sabalan mountain, Iran. J. Adv. Agric. Technol. 2016, 3, 20-25. [CrossRef]

(C) 2019 by the authors. Licensee MDPI, Basel, Switzerland. This article is an open access article distributed under the terms and conditions of the Creative Commons Attribution (CC BY) license (http://creativecommons.org/licenses/by/4.0/). 